\title{
Effect of 2 corpora lutea on blood perfusion, peripheral progesterone, and hepatic steroid-inactivating enzymes in dairy cattle
}

\author{
B. E. Voelz, G. F. Cline, C. G. Hart, C. O. Lemley, and J. E. Larson ${ }^{1}$ \\ Department of Animal and Dairy Sciences, Mississippi State University, Mississippi State 39762
}

\section{ABSTRACT}

The luteal structure that develops postovulation is critical to the facilitation and maintenance of pregnancy in dairy cattle. The objectives of this experiment were to determine if the induction of an accessory corpus luteum (CL), via human chorionic gonadotropin, altered blood perfusion of CL, peripheral concentrations of progesterone, or hepatic steroid-inactivating enzymes. Twenty-eight late-lactation Holstein cows were synchronized using the Ovsynch protocol and randomly assigned to 1 of 2 treatment groups. Cows received either an injection of human chorionic gonadotropin $(1,000$ IU, i.m.) to induce an accessory CL (cows had exactly 2 CL in 1 ovary) or no treatment (cows had exactly 1 CL). Corpora lutea were examined daily from d 10 to 18 (d 0 was induced ovulation) via Doppler ultrasonography and a blood sample was collected. Volume of the CL was recorded, as well as images and videos of each CL, which were analyzed for blood perfusion. On d 13, a liver biopsy was performed to analyze hepatic steroidinactivating enzymes. Cows with 1 or 2 CL had similar peripheral concentrations of progesterone. Cows with 2 CL had similar luteal volumes to cows with 1 CL but cows with 2 CL had greater total luteal blood perfusion. Hepatic enzyme [cytochrome P450 (CYP) 1A, 3A, and $2 \mathrm{C}$, aldo-keto reductase $1 \mathrm{C}$, and uridine diphosphate glucuronosyltransferase] activities did not differ between cows with 1 and $2 \mathrm{CL}$. Overall, the observed increase in total luteal blood perfusion in cows with 2 CL did not correspond to differences in peripheral concentrations of progesterone or clearance of progesterone measured by the hepatic enzyme activity. This could indicate that induction of an accessory CL would not affect concentrations of progesterone necessary to maintain pregnancy.

Key words: blood perfusion, corpus luteum, progesterone

Received July 8, 2014.

Accepted September 15, 2014.

${ }^{1}$ Corresponding author: JLarson@ads.msstate.edu

\section{INTRODUCTION}

Steady declines in reproductive efficiency in dairy cattle have been documented over the past $60 \mathrm{yr}$, including decreased pregnancy rates and increased embryonic mortality. Decreased concentrations of progesterone due to increased catabolism, decreased secretion, or both, could be responsible for some of this reproductive inefficiency (Inskeep and Dailey, 2005). Rhinehart et al. (2009) showed a larger role for progesterone catabolism versus luteal secretion in controlling peripheral concentrations of progesterone during pregnancy in dairy cattle.

Progesterone is catabolized in the liver by enzymes of the cytochrome P450 (CYP) family, aldo-keto reductase (AKR) family, and uridine diphosphate glucuronosyltransferase (UGT). An in vitro study utilizing primary bovine hepatic cell cultures determined that cytochrome P450 2C was the largest contributor to progesterone inactivation followed by AKR1C and CYP3A, respectively (Lemley and Wilson, 2010). Regulation of these enzymes in vivo could be dependent on the rate of substrate delivery via hepatic blood flow. Sangsritavong et al. (2002) found that greater feed intake increased hepatic blood flow and the metabolic clearance rate of progesterone.

Double ovulation is common in dairy cattle and can lead to the undesirable occurrence of twinning. Silva Del Rio et al. (2006) found that $93 \%$ of twins in dairy cattle are nonidentical, meaning that the majority are the result of a double ovulation. Cows carrying a twin pregnancy are 5.4 times more likely to experience pregnancy loss than those carrying singleton pregnancies (López-Gatius et al., 2004). The physiological mechanism for this difference in pregnancy loss still eludes researchers.

Technological advances in ultrasonography have allowed for the monitoring and quantification of blood perfusion of the corpus luteum (CL). The CL is highly vascularized and, with the use of power Doppler ultrasonography, blood perfusion can be recorded. Herzog et al. (2010) assessed the reliability of luteal blood perfusion, via power Doppler ultrasonography, in conjunction with luteal size and circulating concentra- 
tions of progesterone in cattle. They found a positive correlation between luteal blood perfusion and plasma concentrations of progesterone.

Thus, the objective of this study was to determine if the induction of an accessory CL, via human chorionic gonadotropin (hCG), alters blood perfusion of CL, peripheral concentrations of progesterone, or hepatic steroid-inactivating enzymes.

\section{MATERIALS AND METHODS}

All procedures in this study were approved by the Institutional Animal Care and Use Committee of Mississippi State University.

\section{Animals and Experiment}

A total of 28 late-lactation Holstein cows were housed in a freestall barn at the Bearden Dairy Research Center (Starkville, MS). Cows were allowed ad libitum access to a TMR formulated to meet or exceed dietary requirements of lactating cows (NRC, 2001). Average DIM was $289 \pm 60 \mathrm{~d}$ (range of 163 to $399 \mathrm{~d}$ ) and average milk production was $32.4 \pm 9.7 \mathrm{~kg} / \mathrm{d}$. From mid-July to early November, cows had their estrous cycles synchronized using the Ovsynch protocol (Pursley et al., 1995), with d 0 being the day of the second injection of GnRH. Seven days after the completion of Ovsynch (d 7), ovaries were examined using transrectal ultrasonography (10.0- to $5.0-\mathrm{MHz}$ linear-array transducer, MicroMaxx, SonoSite Inc., Bothell, WA). Cows that responded to Ovsynch and had a single CL remained in the study and either received an injection of hCG (1,000 IU i.m.; Chorulon, Intervet Inc., Millsboro, DE) to induce an accessory CL, or received no additional treatment. Cows that did not respond to Ovsynch or that had multiple CL at this time were excluded from the current repetition. Cows that did not respond or were excluded from the previous repetition were re-enrolled using the same process as previously stated.

On d 10, cows that had received hCG were required to have 2 CL and those that failed to produce 1 accessory CL in response to hCG were excluded from the study. Cows in the control group were also examined to ensure that the single CL had not regressed. Cows that failed to respond to the initial synchronization or failed to produce 1 accessory CL were resubmitted to Ovsynch and subsequent treatments and evaluations, with a minimum of a $15-\mathrm{d}$ period between repetitions.

From d 10 to 18 or until CL regression, ovaries were mapped using transrectal ultrasonography (10.0- to 5.0-MHz linear-array transducer, MicroMaxx, SonoSite Inc.). The diameter of each CL was measured and the volume calculated using a previously published method (Vasconcelos et al., 2001). Blood perfusion of the CL was evaluated using the power flow option of the ultrasound machine, and 2 still images and 1 video were recorded for each CL for later analysis. Blood samples were collected daily from d 10 to 18 by venipuncture of the tail in a spray-coated $\mathrm{K}_{2}$ EDTA tube (Becton, Dickinson and Co., Franklin Lakes, NJ) and immediately placed on ice. Within $2 \mathrm{~h}$ of collection, tubes were centrifuged at $2,000 \times g$ at $4^{\circ} \mathrm{C}$ for $20 \mathrm{~min}$, and plasma was frozen at $-20^{\circ} \mathrm{C}$ until later analysis.

On $\mathrm{d} 13$, a liver biopsy was performed following the published methods of Lemley et al. (2010). Briefly, hair was removed on the right side of the cow at the 10th intercostal space with a clipper, and an ultrasound scan of the liver was performed to locate and avoid large hepatic vessels during the biopsy procedure. The external area of the 10th intercostal space was scrubbed 3 times with betadine (Purdue Products L.P., Stamford, $\mathrm{CT}$ ), and a local anesthetic (approximately $10 \mathrm{~mL}$ of $2 \%$ lidocaine hydrochloride; MWI, Boise, ID) was administered. After a short interval, the skin was punctured with a scalpel and the liver sample was collected using a biopsy needle machined at Mississippi State University's Department of Agricultural and Biological Engineering (Mississippi State) following the specifications of Swanson et al. (2000). After the liver sample was collected, it was placed in a cryogenic vial, snap frozen by submersion in liquid nitrogen, and stored at $-80^{\circ} \mathrm{C}$ until analysis of hepatic enzyme activity. The incision site was closed with a small skin staple, which was sprayed with Blu-kote antiseptic (H. W. Naylor Co. Inc., Morris, NY) and removed 5 d later after the incision healed. Cows were observed and body temperatures were taken to monitor for complications. Body weights were recorded before milking on d 12 and after milking on d 13 and averaged. On d 18 after completion of daily measurements and blood sampling, all cows were administered an injection of $\mathrm{PGF}_{2 \alpha}$ (5 mL i.m.; Lutalyse, Zoetis Inc., Kalamazoo, MI) to regress CL present.

\section{Liver Homogenization}

Approximately $100 \mathrm{mg}$ of liver tissue was placed into $1 \mathrm{~mL}$ of potassium phosphate $\left(\mathrm{KPO}_{4}\right)$ buffer $(400$ $\mathrm{m} M, \mathrm{pH}=7.4)$. Samples were then placed into a glass Dounce homogenizer with an additional $1 \mathrm{~mL}$ of $\mathrm{KPO}_{4}$ buffer and homogenized. Liver homogenate samples were placed into microcentrifuge tubes and then centrifuged at $10,000 \times g$ for $10 \mathrm{~min}$ at $4^{\circ} \mathrm{C}$. The supernatant was stored at $-80^{\circ} \mathrm{C}$ until enzyme assays were conducted. The protein concentration of the supernatant was determined by a Coomassie Plus (Bradford) protein 
assay following the manufacturer's protocol (Thermo Scientific, Rockford, IL).

\section{CYP Enzymes}

Assay kits for CYP1A, CYP3A, and CYP2C and $\mathrm{NADPH}$ regeneration solution were purchased from Promega Corporation (Madison, WI) and assays conducted according to Hart et al. (2014). Briefly, reconstitution buffer was added to luciferin detection reagent. Luciferin CEE (CYP1A), luciferin IPA (CYP3A), and luciferin $\mathrm{H}(\mathrm{CYP} 2 \mathrm{C})$ were diluted in $\mathrm{KPO}_{4}$ buffer. Liver homogenates $(30 \mu \mathrm{g}$ of protein per well) and enzymespecific luciferin substrate were added to 96 -well plates in duplicate. Plates were then preincubated for $10 \mathrm{~min}$ (CYP1A and CYP3A) or $30 \mathrm{~min}$ (CYP2C) at $37^{\circ} \mathrm{C}$. Following the incubation, NADPH regeneration solution was added to each well and plates were incubated for $30 \mathrm{~min}$ (CYP1A and CYP2C) at $37^{\circ} \mathrm{C}$ or $10 \mathrm{~min}$ (CYP3A) at room temperature. After the incubation, luciferin detection reagent was added to each well and plates were protected from light and incubated for an additional $20 \mathrm{~min}$ at room temperature. Plates were then placed into a Promega Multi-Plus plate reader and luminescence was measured.

\section{UGT}

The UGT assay kit was purchased from Promega Corporation and the assay performed according to Hart et al. (2014). Briefly, uridine diphosphoglucoronic acid (UDPGA) was added to half the plates to act as reaction wells, and distilled water was added to the other half as control wells. The UGT reaction mixture containing UGT multienzyme substrate was then combined with liver homogenates $(28 \mu \mathrm{g}$ of liver protein per well), and the plates were preincubated for $10 \mathrm{~min}$ at $37^{\circ} \mathrm{C}$. After incubation, detection reagent was added to each of the wells followed by an incubation period of 20 min at room temperature while protected from light. The plates were then analyzed using a Promega MultiPlus plate reader with luminescence detection mode.

\section{AKR1C}

The activity of AKR1C was determined following the published methods of Lemley and Wilson (2010). Briefly, AKR1C was determined using the specific substrate 1-acenapthenol (Pfaltz \& Bauer, Waterbury, $\mathrm{CT}$ ). Enzymatic reactions contained $150 \mu \mathrm{g}$ of cytoplasmic protein, $250 \mu M$ 1-acenapthenol, and $500 \mu M$ NADP. The 1-acenapthenol-dependent reduction of NADP was standardized using the amount of cytoplasmic protein. The reduction of NADP was determined by measuring the amount of light absorbed at $340 \mathrm{~nm}$ for 10 min using a Spectra Max Plus (Sunnyvale, CA) plate reader. The extinction coefficient for NADPH $(6,220 \mathrm{~L} / \mathrm{mol} \cdot \mathrm{cm})$ was used to calculate the rate of reduced NADP in picomoles per minute per milligram of protein.

\section{RIA}

Concentrations of progesterone were determined via RIA using a Coat-A-Count (Siemens Healthcare Diagnostics Inc., Los Angeles, CA) kit and following the manufacturer's protocol. Briefly, standards or $100 \mu \mathrm{L}$ of plasma were added, in duplicate, to the coated tubes. Next, $1 \mathrm{~mL}$ of I-125 progesterone tracer was added to each tube. Following the 3 -h incubation, tubes were aspirated and allowed to drain thoroughly; activity was assessed with a gamma counter (Packard Instrument Company, Meriden, CT). The intraassay coefficient of variation was $3.2 \%$.

\section{Image and Video Analysis}

Images and videos were uploaded from the ultrasound machine and saved to an external location. Images were then analyzed using ImageJ software (version 1.47, US National Institutes of Health, Bethesda, MD) for integrated density to quantify total pixels of blood perfusion. Images and videos were visually scored by 2 independent and trained technicians using a scale from 0 to 9 ( $0=0 \%$ perfusion, $9=100 \%$ perfusion). Images and videos were randomized and presented to technicians with no additional information of cow identification, day, or treatment.

\section{Statistical Analyses}

Treatments were randomly assigned to cows, which were the experimental unit, with the exception of cows that were re-enrolled and responded successfully (n $=5$ ); in those cases, the opposite treatment was assigned. Eleven cows in the control group and 8 cows in the hCG group successfully completed the study. The concentration of progesterone, total luteal volume, and blood perfusion of the CL were analyzed using repeated measurements in the MIXED procedure of SAS (version 9.3, SAS Institute Inc., Cary, NC) with autoregressive order-1 as the covariate structure. The model contained cow, which was considered a random variable, and milk production, DIM, and BW, which were considered covariates. The treatment effect for hepatic enzymes was analyzed using the MIXED procedure of SAS. Means were separated using the PDIFF option of the LSMEANS statement. Pearson correlation coef- 
ficients were determined using the CORR procedure of SAS. Least squares means and pooled standard errors are reported. Statistical significance was declared at $P$ $<0.05$ and a tendency was declared when $P>0.05$ but $\leq 0.10$.

\section{RESULTS}

The response rate for cows producing a single CL on d 7 was $63.3 \%$ (38 of 60 cows). Cows administered hCG produced an accessory CL 36\% (9 of 25 cows) of the time. Peripheral concentrations of progesterone were not different $(P=0.62)$ between cows with $1 \mathrm{CL}(7.19$ $\pm 0.71 \mathrm{ng} / \mathrm{mL})$ and cows with $2 \mathrm{CL}(7.73 \pm 0.84 \mathrm{ng} /$ $\mathrm{mL})$. We detected an interaction $(P=0.02)$ between treatment and day for total luteal volume (Figure 1). On d 10 to 18, total luteal volumes did not differ between treatment groups within a given day.

Total integrated densities were greater $(P=0.001)$ in cows with 2 CL $(7,781.44 \pm 758.06$ pixels $)$ than cows with 1 CL $(4,399.69 \pm 638.95$ pixels $)$. Similarly, blood perfusion scores were greater $(P<0.001)$ in cows with $2 \mathrm{CL}(6.96 \pm 0.32)$ than in cows with $1 \mathrm{CL}(3.82 \pm$ 0.27 ) for visually scored images. We detected a treatment by day interaction $(P=0.02$; Figure 2$)$ for videos visually scored for blood perfusion. Blood perfusion measured from videos was different $(P<0.001)$ between treatment groups for d 10 through 17 but tended to be different $(P=0.10)$ on $\mathrm{d} 18$.

Blood perfusion was adjusted using the ratio of perfusion per volume. The interaction for integrated density per cubic centimeter is shown in Figure 3. Perfusions for integrated density per cubic centimeter were different between treatment groups on d 12, 15, 16, and 18

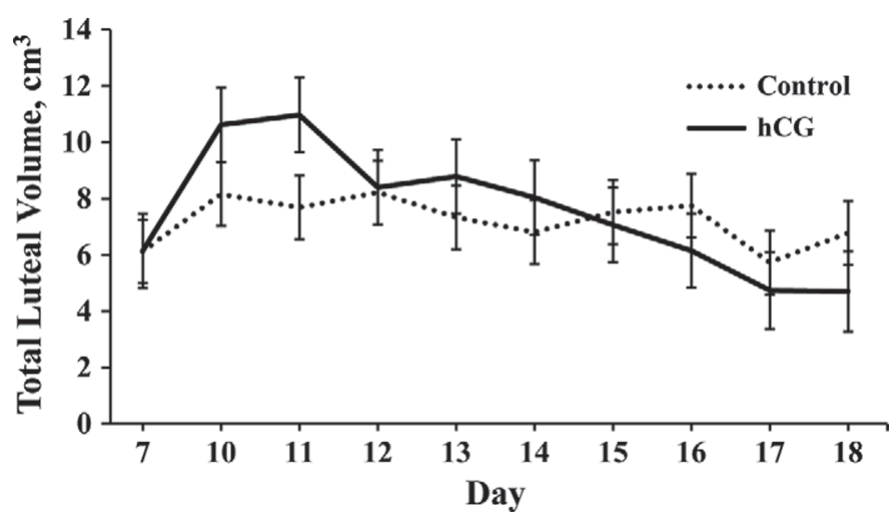

Figure 1. Total luteal volume between cows receiving control (1 corpus luteum, $\mathrm{n}=11$ ) or human chorionic gonadotropin (hCG; 2 corpora lutea, $\mathrm{n}=8$ ) treatments were similar. There was an interaction $(P=0.02)$ between treatment and day for total luteal volume. The $\mathrm{x}$-axis is experiment day, with $\mathrm{d} 0$ being the time of the second injection of GnRH (induced ovulation) during ovulation synchronization.

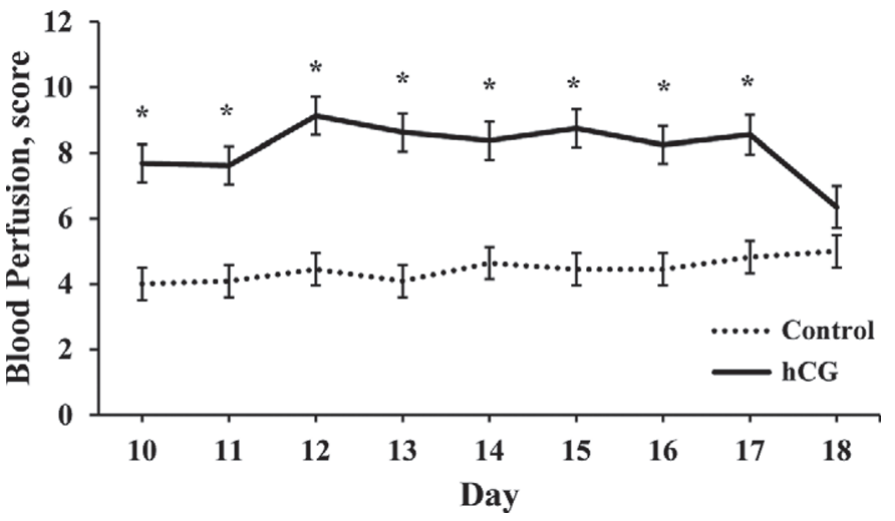

Figure 2. Visual characterization of total perfusion from images on d 10 to 18, between cows receiving control (1 corpus luteum, $\mathrm{n}=$ 11) or human chorionic gonadotropin (hCG; 2 corpora lutea, $\mathrm{n}=8$ ) treatments. A treatment by day interaction of $P \leq 0.02$ was observed. *Indicates days when treatments were different $(P \leq 0.05)$. The $\mathrm{x}$-axis is experiment day, with $\mathrm{d} 0$ being the time of the second injection of $\mathrm{GnRH}$ (induced ovulation) during ovulation synchronization.

$(P<0.02)$. Perfusion scores per cubic centimeter for images $(P=0.009)$ and videos $(P<0.001)$ were different between treatment groups (Figure 4). Perfusion scores per cubic centimeter for videos were also different by day $(P=0.003)$. In all instances of differences, cows with 2 CL had increased perfusion compared with cows with 1 CL.

The activity of hepatic steroid-inactivating enzymes CYP1A, CYP3A, CYP2C, AKR1C, and UGT (Table 1) did not differ $(P>0.18)$ between cows with $1 \mathrm{CL}$ and those with 2 CL based on milligrams of protein and per kilogram of BW on d 13.

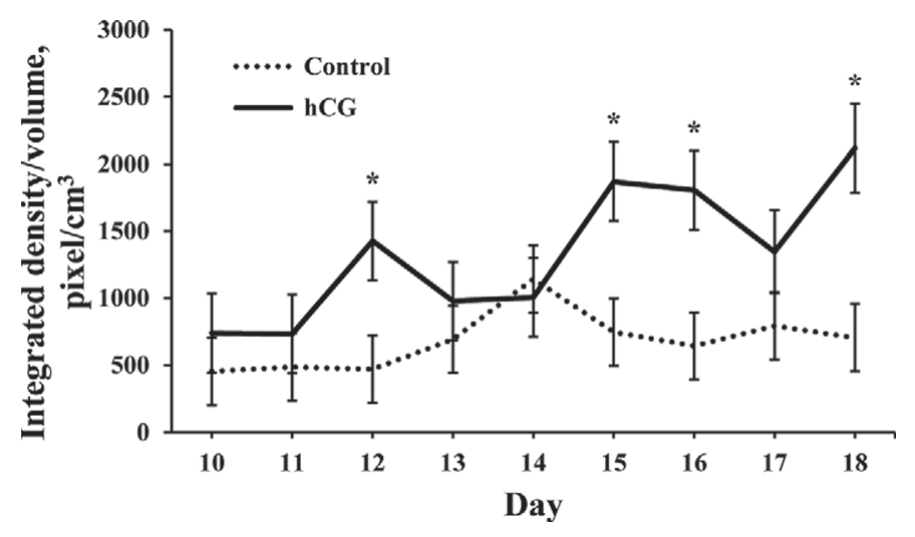

Figure 3. Volume adjusted integrated density perfusion from images on d 10 to 18, between cows receiving control (1 corpus luteum, $\mathrm{n}=11$ ) or human chorionic gonadotropin (hCG; 2 corpora lutea, $\mathrm{n}$ $=8)$ treatments. ${ }^{*}$ Indicates days when treatments were different $(P$ $\leq 0.05)$. The $\mathrm{x}$-axis is experiment day, with d 0 being the time of the second injection of GnRH (induced ovulation) during ovulation synchronization. 
Table 1. Hepatic cytochrome P450 (CYP), aldo-keto reductase (AKR), and uridine diphosphate glucuronsyltransferase (UGT) activities in cows receiving no treatment (control) or receiving an injection of human chorionic gonadotropin (hCG) to induce an accessory corpus luteum

\begin{tabular}{|c|c|c|c|c|}
\hline Enzyme $^{1}$ & $\begin{array}{c}\text { Control } \\
(\mathrm{n}=11)\end{array}$ & $\begin{array}{c}\mathrm{hCG} \\
(\mathrm{n}=8)\end{array}$ & $\mathrm{SE}$ & $P$-value \\
\hline \multicolumn{5}{|l|}{ CYP1A } \\
\hline $\mathrm{RLU} /(\min \cdot \mathrm{mg}$ of protein $) \times 10^{4}$ & 44.26 & 35.09 & 4.74 & 0.18 \\
\hline RLU/(min·kg of BW) & 20.46 & 15.95 & 2.41 & 0.19 \\
\hline \multicolumn{5}{|l|}{ CYP2C } \\
\hline $\mathrm{RLU} /(\min \cdot \mathrm{mg}$ of protein $) \times 10^{3}$ & 4.58 & 4.60 & 0.39 & 0.98 \\
\hline $\mathrm{RLU} /(\min \cdot \mathrm{kg}$ of $\mathrm{BW})$ & 0.21 & 0.21 & 0.02 & 0.90 \\
\hline \multicolumn{5}{|l|}{ CYP3A } \\
\hline $\mathrm{RLU} /(\min \cdot \mathrm{mg}$ of protein $) \times 10^{5}$ & 15.76 & 14.80 & 1.55 & 0.66 \\
\hline $\mathrm{RLU} /(\min \cdot \mathrm{kg}$ of $\mathrm{BW})$ & 73.23 & 67.48 & 8.42 & 0.63 \\
\hline \multicolumn{5}{|l|}{ AKR1C } \\
\hline $\mathrm{pmol} /(\mathrm{min} \cdot \mathrm{mg}$ of protein $)$ & 48.39 & 43.39 & 2.77 & 0.21 \\
\hline $\mathrm{pmol} /(\mathrm{min} \cdot \mathrm{kg}$ of $\mathrm{BW}) \times 10^{3}$ & 24.49 & 20.69 & 2.00 & 0.19 \\
\hline \multicolumn{5}{|l|}{ UGT } \\
\hline $\mathrm{RLU} /(\mathrm{min} \cdot \mathrm{mg}$ of protein $) \times 10^{4}$ & 98.45 & 95.33 & 11.30 & 0.84 \\
\hline $\mathrm{RLU} /(\min \cdot \mathrm{kg}$ of $\mathrm{BW}) \times 10^{8}$ & 6.49 & 6.12 & 0.81 & 0.74 \\
\hline
\end{tabular}

${ }^{1}$ CYP1A, CYP2C, CYP3A, and UGT activity is expressed in relative light units (RLU).

Progesterone tended to be positively correlated with total luteal volume $(P=0.10$; Table 2$)$ but tended to be negatively correlated with milk production $(P$ $=0.06$; Table 2). Image scores, video scores, and integrated density were all positively correlated with each other $(P<0.004$; Table 2$)$ but perfusion scores were not correlated with concentrations of progesterone. Integrated density was positively correlated with total luteal volume $(P=0.04$; Table 2$)$ but image and video perfusion scores were not correlated to total luteal volume. Cytochrome P450 3A was negatively correlated with total luteal volume $(P<0.05)$, but no other hepatic enzymes investigated were correlated with luteal volume, progesterone, or CL blood perfusion.

\section{DISCUSSION}

Expected synchronization rates in dairy cattle using the Ovsynch protocol are approximately $87 \%$ (Vasconcelos et al., 1999). In the current study, response rates using Ovsynch were well below expected outcomes (63.3 vs. $87 \%$ ). Success rates in previous reports using hCG to cause a spontaneous ovulation and induce an acces- sory CL were approximately $70 \%$ (Wallace et al., 2011; Stevenson and Pulley, 2012). The observed response in the current study to hCG to induce an accessory CL $(36 \%)$ was also less than expected. These poor responses could be due to the high ambient temperatures and relative humidity that are experienced in the southeastern United States during the summer months.

Twinning rates are positively correlated with double ovulation rates. The occurrence of twinning is between 2.4 and $5.8 \%$ in dairy cattle (Wiltbank et al., 2000), with $93 \%$ of twins being nonidentical (Silva Del Rio et al., 2006). The incidence of double ovulation, however, is more common than twinning and is reported to be between 5 and 28\% (Fricke and Wiltbank, 1999; LópezGatius et al., 2005; Mann et al., 2007). Beerepoot et al. (1992) estimated that twin births cost producers, on average, $\$ 171$ more per incidence compared with singleton births. Understanding the mechanisms and physiological changes involved with double ovulation could help decrease the incidence of twinning in dairy cattle, with a positive economic impact for producers.

Similar to results in the current study, Mann et al. (2007) determined that dairy cows with a double ovula-

Table 2. Pearson correlations (r) between measurements on d 13

\begin{tabular}{lccc}
\hline Item & Progesterone & $\begin{array}{c}\text { Integrated } \\
\text { density }\end{array}$ & $\begin{array}{c}\text { Image } \\
\text { score }\end{array}$ \\
\hline Progesterone & & 0.19 & 0.25 \\
Total luteal volume & $0.39 \dagger$ & $0.47^{*}$ & 0.28 \\
Milk production & $-0.44 \dagger$ & 0.10 & -0.14 \\
Integrated density & 0.19 & $0.69^{*}$ & $0.69^{*}$ \\
Image score & 0.25 & $0.64^{*}$ & $0.88^{*}$ \\
Video score & 0.05 & &
\end{tabular}




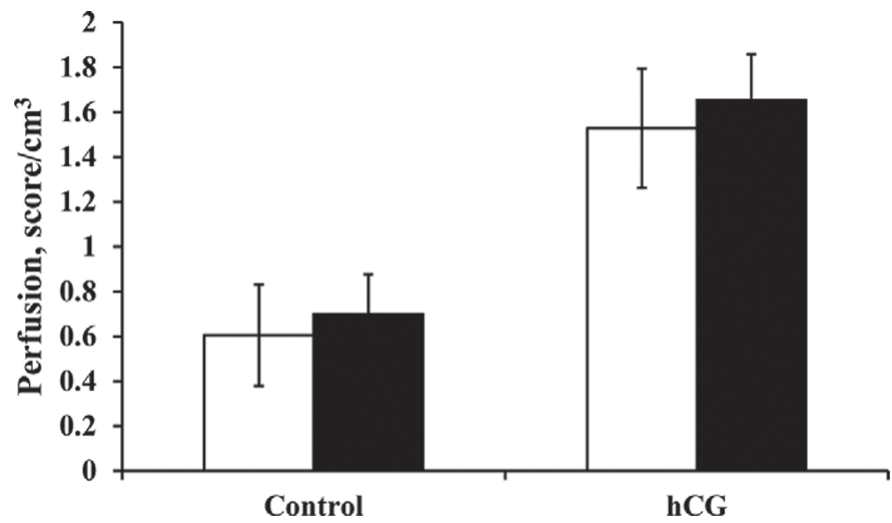

Figure 4. Mean perfusion scores adjusted for corpus luteum volume for images (white bar) and videos (black bar) between cows receiving control ( 1 corpus luteum, $\mathrm{n}=11$ ) or human chorionic gonadotropin (hCG; 2 corpora lutea, $\mathrm{n}=8$ ) treatments. Perfusion scores per cubic centimeter for images $(P=0.009)$ and videos $(P<0.001)$ were different between treatment groups.

tion had similar total luteal weights and concentrations of progesterone. In contrast, Lopez et al. (2005) found that dairy cows with a double ovulation had increased luteal volume but decreased concentrations of progesterone compared with cows with a single ovulation. In beef cattle genetically selected for twinning, Echternkamp et al. (2009) found that cows with a double ovulation had greater total luteal volume and concentrations of progesterone compared with cows with a single ovulation. Interestingly, Sanjabi ewes with a double ovulation had decreased luteal volume but increased concentrations of progesterone compared with ewes with a single ovulation (Shabankareh et al., 2009). Although the size of the hCG-induced ovulatory follicle was not measured, it is expected that it would be smaller than that of a naturally occurring ovulation. A reduction in the size of the ovulatory follicle decreases the size of the subsequent CL (Vasconcelos et al., 2001) and might explain the lack of difference in total luteal volume between cows with $1 \mathrm{CL}$ and cows with $2 \mathrm{CL}$ in the current study.

Luteal volume and luteal blood perfusion can be used as indicators of luteal function and concentrations of peripheral progesterone (Herzog et al., 2010). Herzog et al. (2010) found a positive correlation between luteal volume and concentrations of progesterone $(r=0.69)$ as well as a positive correlation between luteal blood flow and concentrations of progesterone $(\mathrm{r}=0.71)$. In the current study, total luteal volume only tended to be positively correlated with concentrations of progesterone. Furthermore, CL blood perfusion was not correlated with concentrations of progesterone. Despite the increase in perfusion observed in cows with 2 CL in this study, the total luteal volume was similar between the groups.
The system of visually scoring CL blood perfusion is a fairly novel idea, whereas the use of imaging software to determine pixel quantity has been documented previously (Ginther and Utt, 2004; Herzog et al., 2010). In the current study, we found no difference between perfusion scores obtained from images versus videos; therefore, either images or videos can be effective sources for visually scoring CL blood perfusion. The positive correlation between the scores obtained from images and videos with integrated density supports that visual scoring, just like pixel quantification, is an effective way of determining blood perfusion.

Inadequate peripheral concentrations of progesterone are believed to be one underlying cause of early embryonic mortality in high-producing dairy cows (Wiltbank et al., 2006). In the current study, hepatic enzymes were not altered by an induced accessory CL, but it is important to note that we observed no difference in concentrations of progesterone between treatments. In previous studies, an increase in hepatic blood flow increased the metabolic clearance rate of steroid hormones, such as progesterone, thus decreasing the peripheral concentrations (Sangsritavong et al., 2002). Rhinehart et al. (2009) showed a greater role of inactivation than secretion of progesterone in controlling peripheral concentrations. Based on results from the current experiment, we cannot conclude that induction of an accessory CL changes peripheral concentrations of progesterone and thus may not affect embryonic mortality via this mechanism.

\section{CONCLUSIONS}

Overall, the increased blood perfusion of CL in cows with 2 CL did not correspond to increased peripheral concentrations of progesterone or increased clearance as measured by hepatic enzyme activity, perhaps indicating that a double ovulation does not affect progesterone necessary to maintain pregnancy. More research is necessary to determine the underlying cause of decreased fertility and early embryonic mortality in dairy cattle with singleton or twin pregnancies.

\section{ACKNOWLEDGMENTS}

The authors thank the staff at the Joe Bearden Dairy Research Center (Mississippi State) and students A. M. Muth-Spurlock, K. E. Brockus, and C. A. Freeman for their assistance in data collection. This project was supported by the MAFES Special Research Initiative at Mississippi State University. Article is approved for publication as Journal Article No 12544 of the Mississippi Agricultural and Forestry Experiment Station, Mississippi State University. 


\section{REFERENCES}

Beerepoot, G. M., A. A. Dykhuizen, M. Nielen, and Y. H. Schukken. 1992. The economics of naturally occurring twinning in dairy cattle. J. Dairy Sci. 75:1044-1051.

Echternkamp, S. E., R. A. Cushman, and M. F. Allan. 2009. Size of ovulatory follicles in cattle expressing multiple ovulations naturally and its influence on corpus luteum development and fertility. J. Anim. Sci. 87:3556-3568.

Fricke, P. M., and M. C. Wiltbank. 1999. Effect of milk production on the incidence of double ovulation in dairy cows. Theriogenology 52:1133-1143.

Ginther, O. J., and M. D. Utt. 2004. Doppler ultrasound in equine reproduction: Principles, techniques, and potential. J. Equine Vet. Sci. 24:516-526.

Hart, C. G., L. E. Camacho, K. C. Swanson, K. A. Vonnahme, and C. O. Lemley. 2014. Hepatic steroid metabolizing enzyme activity during early, mid, and late bovine pregnancy. Domest. Anim. Endocrinol. http://dx.doi.org/10.1016/j.domaniend.2014.05.003. In press.

Herzog, K., M. Bockhan-Ludenmann, M. Kaske, N. Beindorff, V. Paul, H. Niedmann, and H. Bollwein. 2010. Luteal blood flow is a more appropriate indicator for luteal function during the bovine estrous cycle than luteal size. Theriogenology 73:691-697.

Inskeep, E. K., and R. A. Dailey. 2005. Embryonic death in cattle. Vet. Clin. North Am. Food Anim. Pract. 21:437-461.

Lemley, C. O., K. A. Vonnahme, L. R. Tager, K. M. Krause, and M. E. Wilson. 2010. Diet induced alterations in hepatic progesterone (P4) catabolic enzyme activity and $\mathrm{P} 4$ clearance rate in lactating dairy cows. J. Endocrinol. 205:233-241.

Lemley, C. O., and M. E. Wilson. 2010. Effect of cytochrome P450 and aldo-keto reductase inhibitors on progesterone inactivation in the primary bovine hepatic cell culture. J. Dairy Sci. 93:4613-4624.

Lopez, H., R. Sartori, and M. C. Wiltbank. 2005. Reproductive hormones and follicular growth during development of one or multiple dominant follicles in cattle. Biol. Reprod. 72:788-795.

López-Gatius, F., M. Lopez-Bejar, M. Fenech, and R. H. F. Hunter. 2005. Ovulation failure and double ovulation in dairy cattle: Risk factors and effects. Theriogenology 63:1298-1307.

López-Gatius, F., P. Santolaria, J. L. Yaniz, J. M. Garbayo, and R. H. F. Hunter. 2004. Timing of early foetal loss for single and twin pregnancies in dairy cattle. Reprod. Domest. Anim. 39:429-433.

Mann, G. E., R. S. Robinson, and M. G. Hunter. 2007. Corpus luteum size and function following single and double ovulations in nonlactating dairy cows. Theriogenology 67:1256-1261.

NRC. 2001. Nutrient Requirements of Dairy Cattle. 7th ed. Natl. Acad. Sci., Washington, DC.
Pursley, J. R., M. O. Mee, and M. C. Wiltbank. 1995. Synchronization of ovulation in dairy cattle cows using $\mathrm{PGF}_{2}$ and GnRH. Theriogenology 44:915-923.

Rhinehart, J. D., M. J. Starbuck-Clemmer, J. A. Flores, R. A. Milvae, J. Yao, D. H. Poole, and E. K. Inskeep. 2009. Low peripheral progesterone and late embryonic/early fetal loss in suckled beef and lactating dairy cows. Theriogenology 71:480-490.

Sangsritavong, S., D. K. Combs, R. Sartori, L. E. Armentano, and M. C. Wiltbank. 2002. High feed intake increases liver blood flow and metabolism of progesterone and estradiol- $17 \beta$ in dairy cattle. J. Dairy Sci. 86:2831-2842.

Shabankareh, H. K., J. Habibizad, and M. Torki. 2009. Corpus luteum function following single and double ovulation during estrous cycle in Sanjabi ewes. Anim. Reprod. Sci. 114:362-369.

Silva Del Rio, N., B. W. Kirkpatrick, and P. M. Fricke. 2006. Observed frequency of monozygotic twinning in Holstein dairy cattle. Theriogenology 66:1292-1299.

Stevenson, J. S., and S. L. Pulley. 2012. Characteristics and retention of luteal structures, extended postinsemination cycle, progesterone, and pregnancy-specific protein B in serum after human chorionic gonadotropin treatment of dairy cattle. J. Dairy Sci. 95:4396-4409.

Swanson, K. S., N. R. Merchen, J. W. Erdman Jr., J. K. Drackley, F. Orias, G. N. Douglas, and J. C. Huhn. 2000. Technical note: A technique for multiple liver biopsies in neonatal calves. J. Anim. Sci. 78:2459-2463

Vasconcelos, J. L. M., R. Sartori, H. N. Oliveria, J. G. Guenther, and M. C. Wiltbank. 2001. Reduction in the size of the ovulatory follicle reduces subsequent luteal size and pregnancy rate. Theriogenology 56:307-314.

Vasconcelos, J. L. M., R. W. Silcox, G. J. M. Rosa, J. R. Pursley, and M. C. Wiltbank. 1999. Synchronization rate, size of the ovulatory follicle, and pregnancy rate after synchronization of ovulation beginning on different days of the estrous cycle in lactating dairy cows. Theriogenology 52:1067-1078.

Wallace, L. D., C. A. Breiner, R. A. Breiner, A. R. Spell, J. A. Carter, G. C. Lamb, and J. S. Stevenson. 2011. Administration of human chorionic gonadotropin at embryo transfer induced ovulation of a first wave dominant follicle, and increased progesterone and transfer pregnancy rates. Theriogenology 75:1506-1515.

Wiltbank, M., H. Lopez, R. Sartori, S. Sangsritavong, and A. Gumen. 2006. Changes in reproductive physiology of lactating dairy cows due to elevated steroid metabolism. Theriogenology 65:17-29.

Wiltbank, M. C., P. M. Fricke, S. Sangritasvong, R. Sartori, and O. J. Ginther. 2000. Mechanisms that prevent and produce double ovulations in dairy cattle. J. Dairy Sci. 83:2998-3007. 